\title{
HUBUNGAN PERSEPSI PASIEN TENTANG EMPATI PERAWAT DENGAN KEPUASAAN PASIEN DI RUANG RAWAT INAP RSUD SLEMAN YOGYAKARTA
}

\author{
${ }^{1}$ Nur Hafni Hasim, ${ }^{2}$ Induniasih, ${ }^{3}$ Fajarina Lathu Asmarani \\ 1, 3 ProdiS1 Ilmu Keperawatan Universitas Respati Yogyakarta \\ 2 Jurusan Keperawatan Poltekkes Kemenkes Yogyakarta \\ o_induniasih@yahoo.com
}

\begin{abstract}
Abstrak
Persepsi pasien terhadap sikap empati perawat adalah pandangan pribadi atas sesuatu yang merupakan proses dari menyadari sesuatu objek atau keadaan melalui penggunaan seluruh alat indra. Persepsi pasien menjadi penting karena persepsi sering digunakan untuk melakukan penilaian mutu atau kualitas pelayanan kesehatan. Tingkatan kepuasan pasien yang merupakan keluaran dari persepsi ini dapat digunakan untuk mengevaluasi mutu pelayanan. Tujuan mengetahui adanya hubungan persepsi pasien tentang empati perawat dengan kepuasan pasien di Ruang Inap Kelas III RSUD Sleman.Metode dalam penelitian ini adalah non eksperimen deskriptif analitik dengan pendekatan cross sectional. Populasi dalam penelitian ini adalah pasien sebanyak 324 orang dengan jumlah Sampel 147 yang di pilih berdasarkan accidental sampling dengan pertimbangan kriteria inklusi dan eksklusi. Instrumen penelitian berupa kuesioner. Dianalisis dengan analisa spearman rank. Hasil penelitian menunjukkan persepsi pasien tentang empati perawat berada dalam kategori baik $(75,6 \%)$. Kepuasaan pasien tentang empati perawat berada dalam kategori puas $(86,4 \%)$. Hasil uji Spearman Rank menunjukkan koefisien kolerasi (rho) sebesar 0,688 dengan nilai signifikan $(\rho)$ sebesar 0,000 , lebih kecil dari taraf signifikan yaitu 0,05 $(\rho<0,05)$. Kesimpulan : Ada hubungan antara persepsi pasien tentang empati perawat dengan kepuasaan pasien.

Kata kunci : Persepsi pasien, Empati perawat, Kepuasan pasien
\end{abstract}

\section{THE CORRELATION PERCEPTIONS OF EMPATHY PATIENT WITH NURSE PATIENT SATISFACTION IN THE INPATIENT RSUD SLEMAN YOGYAKARTA}

\begin{abstract}
The patient's perception of the nurse's empathy attitude is a personal view of something which is a process of realizing something object or condition through the use of all sensory devices. Patient perception is important because perception is often used to assess the quality or quality of health services. The level of patient satisfaction which is the output of this perception can be used to evaluate service quality. The purpose of knowing the relationship between patients' perceptions of empathy nurses and patient satisfaction in Class III hospitalization in Sleman Hospital. The method in this study is a non-analytic descriptive experiment with a cross-sectional approach. The population in this study were 324 patients with 147 samples selected based on accidental sampling with consideration of inclusion and exclusion criteria. The research instrument was a questionnaire. Analyzed by Spearman rank analysis. The results showed that patients' perceptions of empathy nurses were in a good category (75.6\%). Patient satisfaction about empathy nurses was in the satisfied category (86.4\%). The results of the Spearman Rank test show the correlation coefficient (rho) of 0.688 with significant value $(\rho)$ of 0,000 , smaller than the significant level of 0.05 ( $\rho$ $<0.05$ ). Conclusion: There is a relationship between patient perceptions about empathy for nurses and patient satisfaction.
\end{abstract}

Keywords: Patient Perception, Nurse Empathy, Patient Satisfaction 


\section{Pendahuluan}

Pemberian pelayanan keperawatan sangat bergantung pada perilaku dalam hubungan interpersonal seorang perawat. Dalam memberikan pelayanan keperawatan meliputi rasa empati, menghargai orang lain dan tenggang rasa. Perilaku empati merupakan salah satu sikap dalam hubungan terapeutik yang merupakan unsur yang sangat penting dalam proses yang berlangsung secara interpersonal. Saat menjalin hubungan komunikasi, empati akan membantu dalam mempererat hubungan antara perawat dengan pasien yang ditanganinya. Sitorus, R, (2007).

Kepuasan pasien adalah tingkat kepuasan dari persepsi pasien dan keluarga terhadap pelayanan kesehatan dan merupakan salah satu indikator kinerja rumah sakit. Bila perawat menunjukkan hal-hal yang bagus mengenai pelayanan kesehatan terutama pelayanan keperawatan dan pasien mengindikasikan dengan perilaku positifnya, maka dapat ditarik kesimpulan bahwa pasien memang puas. (Assaf, 2009).

Mengevaluasi kepuasan terhadap jasa pelayanan yang diterima mengacu pada beberapa faktor, diantaranya adalah komunikasi. Komunikasi dalam hal ini juga termasuk perilaku, tutur kata, keacuhan, keramahan petugas, serta kemudahan mendapatkan informasi dan komunikasi menduduki peringkat tertinggi dalam persepsi kepuasan pasien rumah sakit. Tidak jarang pasien atau keluarganya merasa cukup puas karena dilayani dengan sikap yang menghargai perasaan dan martabatnya. Perasaan puas yang dirasakan pasien disebabkan oleh persepsi pasien. (Suryawati, 2004),

Berdasarkan pengalaman dan pengamatan peneliti, masih banyak ditemui fenomena di lapangan, masih dijumpai perawat yang belum menampilkan citra sebagai tenaga keperawatan yang ramah, murah senyum, dan memandang pasien sebagai pusat perhatian dengan sikap dan tingkah laku yang memberikan asuhan keperawatan yang meliputi rasa empati, menghargai orang lain dan tenggang rasa. Hasil penelitian tentang tingkat kepuasan pasien terhadap sikap empati perawat di instalasi Rawat Inap Penyakit Dalam RS DR. Sardjito Yogyakarta didapat hasil Responden menyatakan sangat puas terhadap sikap empati perawat $0 \%$, puas $36,78 \%$, kurang puas 63,38 , tidak puas $0 \%$. Sebagai gambaran indikator pelayanan rawat inap RSUD Sleman periode tahun 2008 sampai dengan tahun 2011. BOR pada tahun 2008 31,57, tahun 2009 32,42, tahun 2010 33,52 dan pada tahun 2011 yaitu 34,31. RSUD Sleman Yogyakarta Kelas III mempunyai kapasitas tempat sebanyak 82 responden. (Ramadhan, 2004)

Hasil studi pendahuluan penulis melalui observasi pada 15 orang pasien yang di bangsal kelas III yang terdiri dari ruang Cendana, Kenanga, Flamboyan, Edelwis, Bugenvil dan Dahlia tanggal 29 dan 30 November 2011 didapatkan data bahwa perawat yang melalukan asuhan keperawatan tidak pernah memberikan respon verbal maupun nonverbal terhadap apa yang dirasakan pasien dan perawat tidak pernah menyebutkan penyebab apa yang pasien rasakan. Hasil customer satisfaction indeks Maret 2011 di RSUD Sleman, masih ada pasien yang menyatakan ketidakpuasan terhadap perilaku perawat, adapun isi pernyataan untuk perawat pada survey tersebut antara lain mohon para perawat lebih ramah lagi karena ada yang berkesan ada perawat yang galak dan kurang ramah, sebaiknya perawat waktu pasien kesakitan ketika akan melahirkan dihibur dan pemberitahuan informasi ke pasien kurang jelas. Berdasarkan saran yang disampaikan pasien kepada perawat ternyata perawat dalam memberikan asuhan keperawatan kepada pasien kurang ramah dan pada saat pasien kesakitan tidak dihibur atau diberi motivasi, padahal murah senyum dan turut merasakan kesakitan yang dialami pasien dengan memberikan perhatian merupakan bagian dari sikap empati.Tujuan penelitian ini adalah untuk mengetahui hubungan persepsi pasien tentang empati perawat dengan kepuasan pasien di Ruang Inap RSUD Sleman Yogyakarta. 


\section{Metode Penelitian}

Jenis penelitian ini adalah non eksperimen deskriptif analitik dengan pendekatan cross sectional. Populasi adalah keseluruhan objek yang akan menjadi sasaran penelitian, Populasi dalam penelitian ini adalah pasien yang dirawat di Ruang Rawat Inap Kelas III RSUD Sleman Yogyakarta. Data populasi diambil dari data rata - rata BOR pertahun sebanyak 34,31. Dengan jumlah pasien $=$ BOR x $82 \mathrm{TT}=234$ pasien. Sampel dalam penelitian ini sebanyak 147 orang yang telah memenuhi kriteria peneliti. Pengambilan sampel yang dilakukan oleh peneliti adalah accidental sampling, dianalisis dengan tehnik statistik yaitu dengan uji Kendall tau

\section{HASIL PENELITIAN DAN PEMBAHASAN}

Tabel 1. Karateristik Responden di Ruang Rawat Inap RSUDSleman Yogyakarta

\begin{tabular}{|c|c|c|c|}
\hline Karateristik & Kriteria & Jumlah & Persentase \\
\hline \multirow{3}{*}{ Umur } & $18-45$ tahun & 74 & 50.3 \\
\hline & $45-65$ tahun & 47 & 38.0 \\
\hline & $>65$ tahun & 26 & 17.7 \\
\hline \multirow{2}{*}{ Jenis Kelamin } & Laki - laki & 79 & 53.7 \\
\hline & Perempuan & 68 & 46.3 \\
\hline \multirow{4}{*}{ Lama Dirawat } & $3-4$ hari & 112 & 76.2 \\
\hline & $5-6$ hari & 25 & 17.0 \\
\hline & $7-8$ hari & 10 & 6.8 \\
\hline & $>8$ hari & 0 & 0 \\
\hline \multirow{6}{*}{ Pendidikan } & Tidak sekolah & 7 & 4.8 \\
\hline & $\mathrm{SD}$ & 23 & 15.6 \\
\hline & SMP & 51 & 34.7 \\
\hline & SMA & 66 & 44.9 \\
\hline & D3 & 0 & 0 \\
\hline & Sarjana & 0 & 0 \\
\hline \multirow{3}{*}{$\begin{array}{l}\text { Frekuensi } \\
\text { dirawat }\end{array}$} & Satu kali & 93 & 63.3 \\
\hline & Dua kali & 45 & 30.6 \\
\hline & Tiga kali & 9 & 6.1 \\
\hline
\end{tabular}

Tabel 1. menunjukkan bahwa dari 147 responden, jumlah responden paling banyak adalah responden yang mempunyai umur 18 - 45 tahun yaitu 74 orang (50,3\%). Dilihat dari Jenis kelamin, responden laki laki lebih banyak dari perempuan yaitu 79 (53,7\%). Karateristik responden dilihat dari lama responden dirawat, jumlah responden paling banyak adalah pasien yang dirawat selama 3- 4 hari yaitu 112 orang (76.2\%), tingkat pendidikan, sebagian besar responden lulusan SMA yaitu 66 orang $(44,9)$, sedangkan untuk lulusan D3 dan Sarjana yaitu 0\%.

Berdasarkan frekuensi pasien dirawat, jumlah responden yang paling banyak adalah pasien yang dirawat sebanyak satu kali yaitu 93 orang (63.3\%), sedangkan jumlah responden yang paling sedikit adalah responden yang dirawat lebih atau sama dengan tiga kali yaitu 9 orang $(6.1 \%)$ 


\section{Persepsi pasien tentang empati perawat}

Tabel 2. Persepsi pasien tentang empati perawat

di Ruang Rawat Inap RSUD Sleman

\begin{tabular}{ccc}
\hline Persepsi & Frekuensi & Persentase \\
\hline Tidak Baik & - & - \\
Cukup Baik & 23 & 15,6 \\
Baik & 111 & 75.6 \\
Sangat Baik & 13 & 8.8 \\
\hline Jumlah & 147 & 100 \\
\hline
\end{tabular}

Tabel 2. dapat diketahui bahwa sebagian besar responden menilai sikap empati perawat berempati dengan baik. Dilihat dari persepsi pasien yang menilai sikap empati perawat, kebanyakan responden mempersepsikan empati perawat baik. Jumlah responden yang menilai sikap empati perawat di Ruang Rawat Inap RSUD sleman empati dengan baik sebanyak 111 orang (75.5\%), berempati dengan sangat baik 13 orang (8.8\%) dan jumlah responden yang menilai cukup empati 23 orang $(15,6 \%)$.

\section{Kepuasan pasien tentang empati perawat}

Kepuasaan pasien tentang empati perawat diukur juga melalui kepuasaan pasien terhadap respon keakuratan, kejelasan, kealamiahan, kehangatan dan kesejatian. Kepuasan adalah suatu bentuk perasaan seseorang setelah mendapatkan pengalaman terhadap kinerja pelayanan yang telah memenuhi harapan

Tabel 3. Kepuasaan pasien tentang sikap empati perawat di Ruang Rawat Inap RSUD Sleman

\begin{tabular}{ccc}
\hline Tingkat Kepuasaan & F & $\%$ \\
\hline Tidak Puas & - & - \\
Cukup Puas & 20 & 13,6 \\
Puas & 127 & 86,4 \\
Sangat Puas & - & - \\
\hline Jumlah & 147 & 100 \\
\hline
\end{tabular}

Berdasarkan Tabel 3. dapat di ketahui bahwa kepuasaan responden terhadap sikap empati perawat di ruang Rawat Inap RSUD Sleman adalah sebagian besar adalah puas yaitu $127(86,4 \%)$ sedangkan yang cukup puas yaitu 20 (13.6\%).

Tabel 4. Tabulasi Silang antara Variabel Persepsi Pasien Tentang Empati Perawat Dengan Kepuasaan Pasien

\begin{tabular}{|c|c|c|c|c|c|c|c|c|c|c|c|c|}
\hline \multirow{3}{*}{$\begin{array}{c}\text { Persepsi } \\
\text { pasien } \\
\text { tentang } \\
\text { emapti } \\
\text { perawat }\end{array}$} & \multicolumn{8}{|c|}{ Kepuasaan pasien tentang empati perawat } & & & \multirow{3}{*}{$\mathrm{R}$} & \multirow{3}{*}{$\mathrm{P}$} \\
\hline & \multicolumn{2}{|c|}{$\begin{array}{c}\text { Tidak } \\
\text { Puas }\end{array}$} & \multicolumn{2}{|c|}{ Puas } & \multicolumn{2}{|c|}{$\begin{array}{l}\text { Cukup } \\
\text { Puas }\end{array}$} & \multicolumn{2}{|c|}{$\begin{array}{c}\text { Sanagt } \\
\text { Puas }\end{array}$} & \multicolumn{2}{|c|}{ Total } & & \\
\hline & $\mathrm{F}$ & $\%$ & $\mathrm{~F}$ & $\%$ & $\mathrm{~F}$ & $\%$ & $\mathrm{~F}$ & $\%$ & F & $\%$ & & \\
\hline Sangat Baik & 0 & 0 & 13 & 8,8 & 0 & 0 & 0 & 0 & 13 & 8,84 & & \\
\hline Baik & 0 & 0 & 109 & 71,4 & 2 & 1,4 & 0 & 0 & 111 & 75,51 & & \\
\hline Cukup baik & 0 & 0 & 5 & 3,4 & 18 & 12,2 & 0 & 0 & 23 & 15,65 & 0.670 & 0,00 \\
\hline Tidak Baik & 0 & 0 & 0 & 0 & 0 & 0 & 0 & 0 & 0 & 0 & & \\
\hline Jumlah & 0 & 0 & 127 & 86,3 & 20 & 13,6 & 0 & 0 & 147 & 100 & & \\
\hline
\end{tabular}


Hasil analisis menunjukkan koefisien kolerasi (rho) 0,670 dengan nilai signifikan $(\rho)$ sebesar 0,00 . Untuk mengetahui ada tidaknya signifikan hubungan antara persepsi pasien tentang empati perawat dengan kepuasaan pasien RSUD Sleman Yogyakarta, dapat dilihat dari nilai (r). jika nilai (r) hitung lebih besar dari (r) tabel maka terdapat hubungan yang signifikan atau dapat juga dilihat dengan nilai signifikan $(\rho)$. jika nilai signifikan $(\rho<0,05)$ maka terdapat hubungan yang signifikan.Berdasarkan analisis diatas, diperoleh nilai $\rho=0,00$ lebih kecil dari 0,05 , Hal ini berarti ada hubungan yang signifikan antara persepsi pasien tentang empati perawat dengan kepuasaan pasien, dan berdasarkan nilai signifikan yaitu sebesar 0,670 maka keeratan hubungan antara kedua variabel penelitian ini memiliki kekuatan hubungan yang cukup dengan korelasi sejajar. Hubungan yang cukup ini maksudnya adalah bahwa empati bukanlah satu-satunya hal yang mempengaruhi kepuasaan pasien.

\section{Pembahasan}

\section{Persepsi pasien terhadap empati perawat di RSUD Sleman Yogyakarta}

Dari hasil penelitian yang dilakukan, didapatkan bahwa sebagian besar persepsi pasien tentang sikap empati perawat dalam kategori baik, artinya rata - rata pasien mempersepsikan empati perawat RSUD Sleman baik. Persepsi pasien tentang sikap empati perawat yang baik ini dapat dipengaruhi oleh usia. Usia responden terbanyak yang berempati yaitu 18 - 45 sebanyak 54 orang (36,7\%), dimana fungsi kognitif dan panca indra masih baik sehingga dapat mempersepsikan dengan tepat, selain semakin cukup umur, tingkat kematangan dan kekuatan seseorang akan lebih matang dalam berfikir. Sebagian besar pasien berempati dengan baik kebanyakan sudah dirawat selama 3 - 4 hari yaitu 88 orang $(59,8 \%)$, dimana pasien telah mendapat pengalaman dirawat, sehingga bisa mempersepsikan empati perawat dengan baik. Hal ini sesuai dengan teori yang menyatakan bahwa proses terjadi persepsi berasal dari kognitif seseorang yang dipengaruhi oleh pendidikan, usia, pengalaman. Proses terjadinya persepsi perlu fenomena dan persepsi, dan yang terpenting dari fenomena dan persepsi adalah perhatian. Teori diatas selaras dengan hasil penelitian, dimana sebagian besar pasien yang dirawat berlatar belakang pendidikan SMA dan berempati dengan baik sebanyak. (Widayatun, 1999).

Hasil penelitian juga ditemukan bahwa ada responden yang berpendidikan rendah tetapi memliliki persepsi yang baik terhadap empati perawat. Ini menunjukkan bahwa pendidikan bukan merupakan faktor utama yang mempengaruhi persepsi seseorang. Faktor pendidikan merupakan faktor penting yang mempengaruhi responden dalam menerima dan memahami informasi yang diberikan, tetapi pendidikan bukanlah satu - satunya yang menentukan seseorang dalam mempersepsikan sesuatu, karena adanya responden yang berpendidikan rendah tetapi dapat mempersepsikan empati perawat dengan baik, hal tersebut disebabkan karena pengalaman. (Musliha, 2009).

\section{Kepuasaan pasien terhadap sikap empati perawat di RSUD Sleman Yogyakarta}

Beradasarkan penelitian yang dilakukan didapatkan bahwa sebagian besar pasien menyatakan puas tentang empati perawat. Artinya rata rata pasien puas dengan empati perawat. Pasien merasa puas dengan empati dapat di pengaruhi dari factor internal. Factor internal yang di maksud adalah jenis kelamin, usia, pandidikan. Dalam penelitian yang terbanyak cukup puas yang berjenis kelamin laki laki yaitu 14 orang $(9,5)$. Sedangkan usia terbanyak yang menyatakan puas yaitu 18 - 45 tahun yaitu 62 orang $(42,1)$ sedangkan berdasarkan pendidikan terbanyak SMA yaitu 59 orang $(40,1)$.

Hasil peneltian tersebut sesuai dengan penelitian yang menyatakan bahwa responden yang berusia muda (kurang dari 25 tahun) lebuh banyak yang menyatakan tidak 
puas dibandingkan yang berusia tua, responden laki laki lebih banyak menyatakan tidak puas dibandingkan dengan perempuan, responden yang berpendidikan tinggi banyak yang menyatakan tidak puas dibandingkan responden yang berpendidikan rendah. (Aday, et al, 1980)

Pendapat lain menyatakan bahwa dalam mengevaluasi kepuasaan terhadap jasa pelayanan yang diterima mengacu pada beberapa factor diantaranya adalah komunikasi. Komunikasi menduduki peringat tertinggi dalam persepsi kepuasaan pasien di rumah sakit. Tidak jarang pasien atau keluarga merasa puas karena dilayani dengan sikap yang menghargai perasaan dan martabatnya. (Suryawati, 2004), Teori tersebut selaras dengan penelitian ini, dimana komunikasi yang didalamnya tedapat empati berpengaruh terhadap kepuasaan pasien. Penelitian lain yang selaras dengan hasil penelitian ini adalah penelitian yang menemukan ada hubungan positif antara komunikasi terapeutik dengan kepuasaan pasien. (Munfaidah, 2008)

\section{Hubungan persepsi pasien tentang empati perawat dengan kepuasaan pasien di Ruang Rawat Inap RSUD Sleman}

Analisis hubungan persepsi pasien tentang empati perawat dengan kepuasaan pasien didapatkan ada hubungan yang signifikan antara persepsi pasien tentang empati perawat dengan kepuasaan pasien, dan berdasarkan nilai signifikan yaitu sebesar 0,670 maka keeratan hubungan antara kedua variabel penelitian ini memiliki kekuatan hubungan yang cukup dengan kolerasi sejajar.

Hubungan yang cukup ini maksudnya adalah bahwa empati perawat bukan merupakan factor utama yang mempengaruhi kepuasaan pasien. Hal lain yang dapat mempengaruhi kepuasaan pasien adalah kualitas produk atau jasa, kuallitas pelayanan, factor emosional, harga/biaya dan lingkunga (Aldina, 2007). Sedangkan korelasi sejajar searah berarti semakin baik persepsi pasien tentang empati perawat maka semakin tinggi kepuasaan pasien.

Hasil peneltian ini selaras dengan pendapat yang menyatakan bahwa apabila perawat mampu melakukan hubungan iinterpersonal dengan pasien secara baik serta memberikan perhatian yang penuh maka kepuasaan pasien akan meningkat sehubungan dengan hal tersebut, sedangkan penelitian ini mendapat hasil ada hubungan antara persepsi pasien tentang empati perawat dengan kepusaan pasien, dimana empati perawat yang dinilai perawat mendengar keluhan pasien, memberikan komentar terhadap apa yang dirasakan pasien, menjelaskan cara mengatasi masalah pasien, memberikan informasi yang jelas pada pasien, menjelaskan pada pasien dengan kata kata sendiri, berbiacara dengan suara yang lembut, memelihara kontak mata, melayani dengan penuh kesabaran dan menghargai dan menghormati pasien akan meningkatkan kepuasaan pasien (Damaiyanti, 2008).

Berdasarkan hasil penelitian, ada responden yang mempersepsikan empati perawat sangat baik tetapi merasa kurang puas. Hal ini menunjukkan ada factor lain yang mempengaruhi kepuasaan pasien yaitu salah satunya kualitas pelayanan perawatan. Kualitas pelayanan yang dimaksud yaitu fasilitas yang disediakan rumah sakit, outcome perawatan yang diterima.

Hasil penelitian ini selaras dengan teori yang menyatakan bahwa kepuasan pasien di pengaruhi banyak factor yaitu pendekatan dan perilaku petugas, mutu informasi yang dierima seperti apa yang di kerjakan apa yang diharap, prosedur perjanjian, waktu tunggu, fasilitas umum yang teersedia, fasilitas perhotelan untuk pasien seperti mutu makanan, privacy, dan pengaturan kunjungan dan perawatan yang dterima. (Wijono, 2000) 
Penelitian yang lain dengan judul Hubungan Kualitas Pelayanan dengan kepuasaan Pasien di RSUD Sleman Yogyakarta, untuk dimensi kualitas pelayanan perawatan (tangible, reliability, responsivenes, assurance dan empathy), dari kelima aspek tersebut berpengaruh positif terhadap kepuasaan pasien, walaupun dimensi empati bukan merupakan dimensi pelayanan yang mempunyai hubungan paling kuat. (Jedho, 2003)

Peneltian ini sesuai juga dengan penelitian lain yang meneliti tentang hubungan antara komunikasi terapeutik perawat dengan kepuasaan, dalam penelitiannya mendapatkan bahwa pasien merasa puas terhadap sikap perawat dalam hubungan terapeutik diantaranya sikap dan perilaku yang perlu diperhatikan adalah bersikap ramah, mendengarkan dan memperhatikan setiap keluhan, punya waktu dalam merawat, merawat dengan sentuhan lembut dan berusaha mengerti perasaan pasien, memberikan kesempatan pasien untuk mengeluarkan isi hati. (Pertiwi, 2002).

Hasil penelitian ini masih ada pasien yang menilai pertanyaan apakah perawat memberikan komentar terhadap apa yang anda rasakan, responden terbanyak memberikan penilaian pada kategori sering yaitu 72 orang (49\%.). Hal ini dapat disebabkan karena beban kerja perawat, dalam satu shift dijaga oleh 4 perawat dengan jumlah pasien yang banyak, yang seharusnya dalam system MPKP primer rationya 1:5 (perawat : pasien), sehingga perawat tidak memberikan komentar terhadap yang dirasakan pasien. Pengelolaan tenaga kerja yang tidak direncanakan dengan baik dapat menyebabkan keluhan yang subyektif, beban kerja semakin berat, tidak efektif dan tidak efisien yang memungkinkan ketidakpuasan bekerja yang pada akhirnya mengakibatkan turunnya kinerja dan produktivitas serta mutu pelayanan yang merosot.

Hasil penelitian yang dilakukan oleh tentang tingkat kepuasaan pasien terhadap sikap empati perawat di Instalasi rawat Inap Kelas I Penyakit dalam RS. Dr. Sardjito Yogyakarta menunujukkan hasil yang berbeda dengan hasil penelitian ini. mengemukakan bahwa sebagian besar responden menyatakan kurang puas terhadap sikap empati perawat sedangkan hasil penelitian ini responden menyatakan puas terhadap sikap empati, hasil ini berbeda karena tempat penelitian yang berbeda, tempat penelitian yang digunakan Ramadhan adalah bangsal penyakit dalam kelas I dimana pasien kelas I mempunyai harapan yang tinggi tentang pelayanan yang diberikan sesuai dengan biaya yang dikeluarkan. (Ramadhan, 2004). Hal tersebut terkait dengan teori yang di kemukakan yaitu Harga atau biaya merupakan aspek terpenting dalam penentu kualitas adalah mencapai kepuasaan pasien, namun demikian hal ini mempengaruhi pasien dari segi biaya yang dikeluarkan, biasanya semakin tinggi harga perawatan semakin tinggi harapan pasien. (Aldina, 2007).

\section{Kesimpulan}

Ada hubungan yang signifikan antara persepsi pasien tentang empati perawat dengan kepuasaan pasien di Ruang Rawat Inap RSUD Sleman Yogyakarta, dengan koefisien kolerasi (rho) sebesar 0,688 dengan nilai signifikan $(\rho)$ sebesar 0,000, lebih kecil dari taraf signifikan yaitu $0,05(\rho<0,05)$.Empati membantu dalam mempererat hubungan antara perawat dengan pasien melalui mendengarkan dan memperhatikan setiap keluhan, punya waktu dalam merawat, merawat dengan sentuhan lembut dan berusaha mengerti perasaan demi kepuasan pasien

\section{Daftar Pustaka}

Aday, L.A. et al, (1980) health care in the U.S., Equitable for Whom?, Publicatioan

Aldina,Y. (2007). Persepsi Pasien terhadap Pelayanan Kesehatan. 
Assaf, MD, (2009). Mutu Pelayanan Kesehatan, Jakarta. EGC

Damaiyanti, M, (2008). Komunikasi Terapeutik. Jakarta: Salemba Medika

Jedho, blais. (2003), Hubungan Hubungan Kualitas Pelayanan dengan kepuasaan Pasien di RSUD Sleman Yogyakarta, Skripsi Prodi Ilmu Keperawatan Universitas Respati Yogyakarta.

Munfaidah Lili. (2008) . Hubungan Antara Komunikasi Terapeutik dengankepuasaan pasien rawat Inap bangsal medical Beadh Panemnahan Senopati Bantul Yogyakarta. Tidak di terbitkan. Program Studi S1 Keperawatan Universitas Respati Yogyakarta

Musliha, (2009). Komunikasi Keperawatan (plus materi komunikasi terpeutik). Yogyakarta : Nuha Medika

Pertiwi, (2002). Hubungan Antara Komunikasi Terapeutik dengan kepuasaan pasien rawat Inap RS Sardjito Yogyajarta Skripsi Keperawatan Tidak diterbitkan, Universitas Gajah Mada Yogyakarta

Ramadhan, A., (2004), Tingkat kepuasan pasien terhadap sikap empati perawat di Instalasi Rawat Inap I Penyakit Dalam RS. Dr Sardjito Yogyakarta. Skripsi Keperawatan Tidak diterbitkan, Universitas Gajah Mada Yogyakarta

Sitorus,R, (2007). Model Praktek Keperawatan Profesi di Rumah Sakit, Jakarta: EGC

Suryawati, C., (2004), Kepuasan pasien Rumah Sakit (Tinjauan Teoritis dan penerapannya pada penelitian), Jurnal Manajemen Pelayanan Kesehatan. Vol. 07/NO.04/Desember 2004

Widayatun, T. M., (1999). Ilmu Perilaku, CV sugeng seto, perpustakaan nasional

Wijono, (2000), Mutu pelayanan Rumah Sakit, PERSI, jakarta 